\title{
MODIFIKASI PEMBELAJARAN STATISTIKA MATEMATIKA \\ DENGAN METODE PETA KONSEP MELALUI \\ PENDEKATAN ANALOGI ${ }^{1)}$
}

\author{
Triyanto $^{2)}$
}

\begin{abstract}
ABSTRAK
Tujuan dari penelitian ini adalah untuk mengembangkan dan menerapkan model dan perangkat pembelajaran Statistika Matematika I melalui modifikasi pembelajaran dengan metode peta konsep melalui pendekatan analogi, dengan harapan kualitas pembelajaran dapat ditingkatkan.

Sejalan dengan tujuan penelitian tersebut maka penelitian ini merupakan penelitian pengembangan dengan model 4- $D$. Sedangkan dalam penerapannya, penelitan ini menggunakan metode diskriptif kuantitatif untuk mengetahui pengaruh pembelajaran peta konsep melalui pendekatan analogi (yang dikembangkan) terhadap prestasi belajar mahasiswa pada mata kuliah Statistika Matematika I. Populasi dalam penelitian ini adalah seluruh mahasiswa Program Studi Pendidikan Matematika, Fakultas Keguruan dan IImu Pendidikan, Universitas Sebelas Maret Surakarta. Sedangkan sampel yang digunakan dalam penelitian ini adalah 70 mahasiswa yang secara acak dari mahasiswa yang mengambil mata kuliah Statistika Matematika I tahun akademik 2010/2011. Dari sampel tersebut 35 mahasiswa ditempatkan dalam kelas eksperimen dan 35 mahasiwa yang lain ditempatkan dalam kelas kontrol.

Hasil penelitian ini adalah 1) Telah dikembangkan perangkat pembelajaran yang berupa bahan ajar dan RPP untuk mata kuliah Statistika Matematika I yang mengacu pada pembelajaran peta konsep melalui pendekatan analogi. 2) Terdapat pengaruh positif pembelajaran peta konsep melalui pendekatan analogi pada mata kuliah Statistika Matematika I di Program Studi Pendidikan Matematika Fakultas Keguruan dan IImu Pendidikan Universitas Sebelas Maret Surakarta.
\end{abstract}

Kata Kunci : Statistika Matematika, Peta Konsep, Analogi

1) Artikel hasil penelitian

2) Staf Pengajar pada Program Studi Pend. Matematika, FKIP, UNS

\section{PENDAHULUAN}

Statistika Matematika merupakan salah satu mata kuliah yang diajarkan di Program Studi Pendidikan Matematika Fakultas Keguruan dan IImu Pendidikan Universitas Sebelas Maret Surakarta. Mata kuliah ini diberikan dalam 2 semester yaitu Statistika Matematika I di semester 5 dengan bobot 3 SKS dan Statistika Matematika II di semester 6 dengan bobot 3 SKS. Tujuan perkuliahan Statistika Matematika adalah memberikan pemahaman dasar kepada mahasiswa mengenai 
konsep dan teori statistika. Secara garis besar, topik-topik yang diberikan adalah : teori probabilitas, distribusi dari variabel random, ekspektasi matematika, distribusi khusus dan transformasi variabel random (Statistika Matematika I ) serta estimasi titik, estimasi interval dan uji hipotesis (Statistika Matematika II). Menilik tujuan yang disebutkan, mata kuliah ini tentunya penting untuk dikuasai mahasiswa mengingat pemahaman mengenai Statistika Matematika akan sangat diperlukan oleh mahasiswa dalam melakukan penelitian, khususnya dalam rangka penyelesaian tugas akhir (skripsi) yang pada umumnya merupakan penelitian kuantitatif.

Namun disisi lain, dari hasil pengamatan yang dilakukan ternyata prestasi mahasiswa dalam mata kuliah Statistika Matematika kurang memuaskan. Dari analisa awal, kelemahan mahasiswa dalam mempelajari Statistika Matematika adalah mahasiswa hanya mampu menghitung kumpulan angka-angka dengan segudang rumus Statistika yang telah dihapal, tanpa memahami konsep yang penting dan mendasar dari Statistika itu sendiri. Padahal semestinya belajar Statistika Matematika bukan hanya sekedar menghafal dan bukan pula sekedar mengingat rumus-rumus, tetapi dibutuhkan pengertian, pemahaman akan suatu persoalan dan pengembangan intelektual siswa dalam mengaitkan informasi baru dengan konsep-konsep yang sesuai dengan apa yang telah dimilikinya. Pokokpokok pikiran inilah yang harus dikembangkan dalam penyelenggaraan kegiatan belajar Statistika Matematika, supaya proses belajar bermakna dapat terjadi.

Disinilah peran guru sebagai salah satu sumber belajar sangat dibutuhkan kemampuannya dalam mengemas suatu pembelajaran yang dapat membantu siswa agar mampu mengkonstruksi sendiri pengetahuannya. Dalam kaitan dengan hal tersebut, dalam mengajar guru haruslah menekankan suatu pemahaman konsep pada diri siswa, yaitu dengan mengarahkan pembelajaran melalui apa yang dipikirkan, dilihat, didengar atau yang telah dilakukan siswa dalam menuangkan suatu gagasan atau ide yang telah dimiliki siswa sebelumnya. Untuk selanjutnya, peran guru dapat dianalogikan sebagai perantara atau konsultan yang dapat membantu merancang "Jembatan Konsep" yang menghubungkan gagasan yang telah ada pada diri siswa dengan konsep yang sedang dan akan dipelajari.

Dalam pada itu, teknologi pembelajaran telah berkembang begitu pesat. Dalam beberapa tahun terakhir telah berkembang berbagai model pembelajaran 
yang sebagian besar menekankan pada pembelajaran yang "menyenangkan" dimana mahasiswa akan dapat menikmati belajar, tertarik dengan materi yang diajarkan dan pada akhirnya dapat tercapai tujuan dari pembelajaran yang dilakukan. Sowey (2001) dalam artikelnya memberikan gambaran untuk keberhasilan pembelajaran statistika dengan membuat statistika sebagai kenangan, yaitu dengan menampilkan berbagai ilustrasi yang berkesan. Sementara itu Martin (2003) dalam tulisannya menawarkan pembelajaran dengan analogi, dimana pembelajaran ini menekankan pemahaman konsep dari materi yang diajarkan melalui berbagai ilustrasi yang sesuai dengan materi yang diajarkan. Pemilihan ilustrasi yang akan digunakan harus merupakan sesuatu yang sudah dikenal atau bahkan udah melekat pada diri mahasiswa, sehingga diharapkan mahasiswa akan lebih mudah mencerna konsep dari materi yang diajarkan.

Sementara itu, pemahaman konsep yang kuat dengan adanya pembelajaran analogi, tentunya metode Peta Konsep menjadi salah satu alternatif yang menarik dalam pembelajaran Statistika Matematika. Hal tersebut mengingat karakter dari mata kuliah Statistika Matematika yang lebih dominan penguasaan konsep-konsep statistika daripada aplikasi statistika itu sendiri. Dengan peta konsep dapat diperlihatkan bagaimana konsepkonsep dalam statistika saling terkait, dan dapat dihubungkan menjadi proporsi yang bermakna. Dengan memberi hubungan antara konsep-konsep tentunya akan memberikan ruang yang lebih mudah bagi mahasiswa dalam memahami konsep secara utuh, serta keterkaitan antara konsep yang satu dengan yang lain.

Mengingat begitu pentingnya mata kuliah Statistika Matematika bagi mahasiswa, baik dalam rangka penyelesaian tugas akhir (skripsi) maupun dalam pengembangan karir di dunia kerja, maka dengan memodifikasi berbagi referensi tentang pembelajaran Statistika Matematika, pada penelitian ini akan diupayakan peningkatan kualitas pembelajaran Statistika Matematika I di Program Studi Pendidikan Matematika, Fakultas Keguruan dan IImu Pendidikan, Universitas Sebelas Maret Surakarta, dengan metode Peta Konsep melalui pendekatan Analogi. 


\section{METODE PENELITIAN}

Penelitian ini merupakan penelitian pengembangan dengan model 4- $D$ yang terdiri dari empat tahap yakni define, design, develop dan dessimenete. Sedangkan dalam penerapannya untuk mengetahui pengaruh pembelajaran peta konsep melalui pendekatan analogi terhadap prestasi belajar mahasiswa pada mata kuliah Statistika Matematika I, dilakukan penelitian eksperimental dengan memberikan perlakuan pada kelompok eksperimen menggunakan model pembelajaran peta konsep melalui pendekatan analogi, dan pembelajaran secara konvensional pada kelompok kontrol. Pada tiap akhir kelompok kompetensi dasar (KKD) diadakan evaluasi dan membandingkan hasil evaluasi dari kelompok ekperimen dengan kelompok kontrol dengan menggunakan uji $\mathrm{t}$

Populasi dalam penelitian ini adalah seluruh mahasiswa Program Studi Pendidikan Matematika, Fakultas Keguruan dan IImu Pendidikan, Universitas Sebelas Maret Surakarta. Sedangkan sampel yang digunakan dalam penelitian ini adalah 70 mahasiswa yang secara acak dari mahasiswa yang mengambil mata kuliah Statistika Matematika I tahun akademik 2010/2011. Dari sampel tersebut 35 mahasiswa ditempatkan dalam kelas eksperimen dan 35 mahasiwa yang lain ditempatkan dalam kelas kontrol.

\section{HASIL PENELITIAN DAN PEMBAHASAN}

\section{A. Hasil Pengembangan Perangkat Pembelajaran}

Perangkat Pembelajaran yang dikembangakan dalam penelitian ini adalah Rencana Pelaksanaan Pembelajaran (RPP) dan bahan ajar yang mengacu pada pembelajaran peta konsep melalui pendekatan analogi. Pada pengembangan perangkat pembelajaran digunakan model 4-D (four $D$ model) yang terdiri dari empat tahap yakni define, design, develop dan dessimenete. Hasil dari setiap tahap adalah sebagai berikut :

\section{Tahap define}

Pada tahap ini dilakukan penentuan karakter dari materi ajar beserta instrument yang mendukungnya. Seperti yang telah dijelaskan didepan bahwa materi pembelajaran pada penelitian ini mata kuliah Statistika Matematika I yang diberikan pada mahasiswa semester 5 dengan bobot 3 SKS. Secara garis besar, topik-topik yang diberikan untuk Statistika Matematika I adalah : teori probabilitas, distribusi dari variabel random, ekspektasi matematika, distribusi khusus dan transformasi variabel random. Untuk dapat megikuti mata kuliah Statistika Matematika I, mahasiswa harus sudah pernah menempuh 
mata kuliah Kalkulus 1 (semester 1), Kalkulus 2 (semester 2) dan Metode Statistika 1 (semester 3). Pertimbangan penentuan persyaratan tersebut antara lain karena untuk mempelajari topik-topik pada Statistika Matematika I diperlukan limit fungsi (kalkulus 1), differensial dan intergral (Kalkulus 2) maupun dasar-dasar probabilitas (Metode Statistika 1).

\section{Tahap design}

Pada tahap ini disusun prototipe perangkat pembelajaran (RPP dan Bahan Ajar) dengan memperhatikan hasil pada tahap define serta memperhatikan model pembelajaran peta konsep melalui pendekatan analogi.

Untuk perangkat pembelajaran yang berupa bahan ajar kuliah, didasarkan pada pola pikir pembelajaran peta konsep dan analogi. Pada setiap awal BAB dalam bahan ajar selalu disajikan diagram alur yang mengkaitkan antara suatu konsep dengan konsep yang lain. Dengan pola ini, mahasiswa seakan-akan dibimbing untuk melewati "jembatan konsep", sehingga diharapkan akn lebih terarah. Sebagai contoh untuk memahami konsep fungsi distribusi, mahasiswa harus singgah dahulu ke ruang probabilitas dengan peta konsep sebagai berikut : 


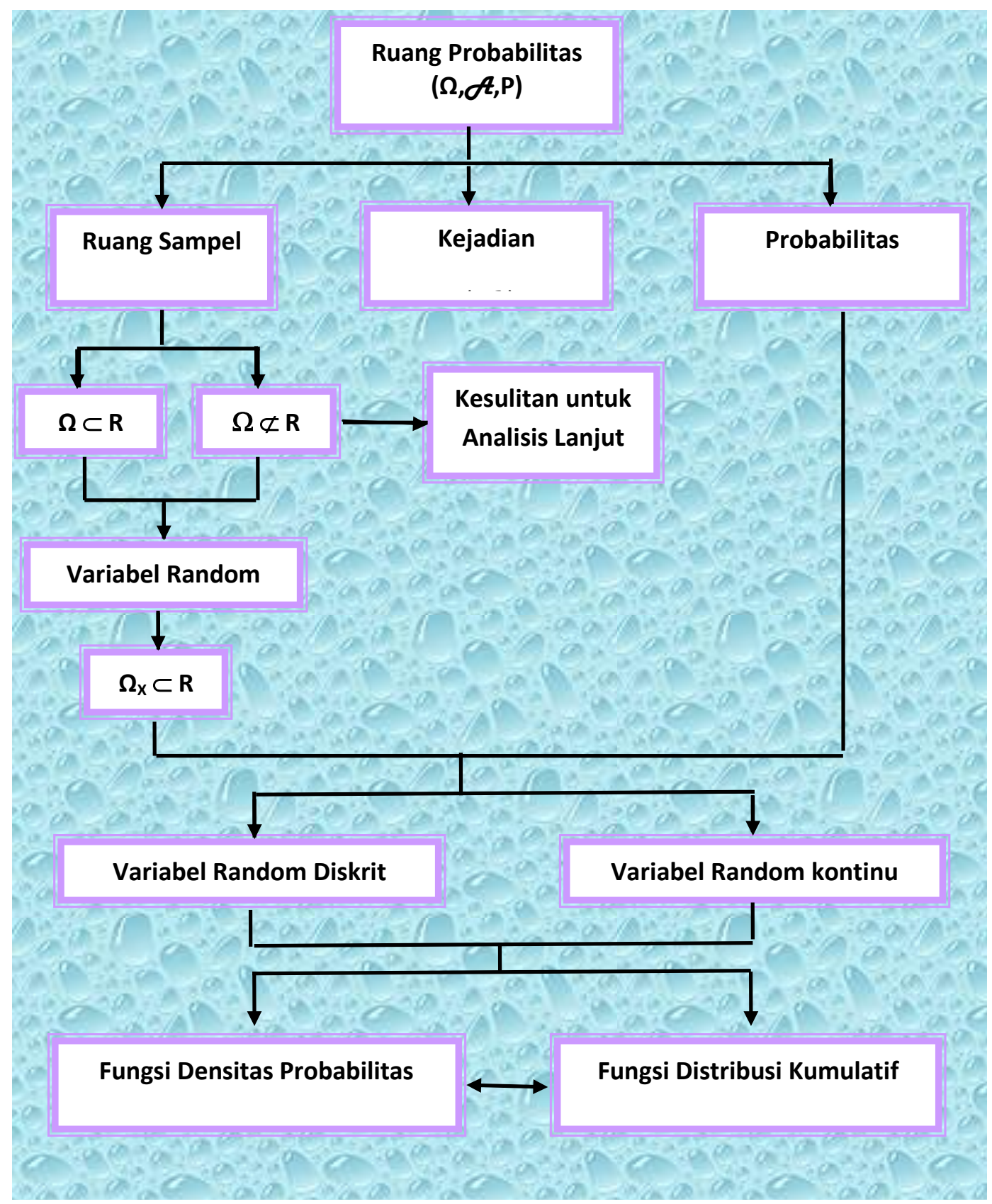

Sementara untuk memahami masing-masing konsep yang alurnya sudah jelas tersebut dengan pendekatan analogi, dimana dalam proses pembelajaran mempertimbangkan empat tahap berpikir analogi, yaitu : Access, Mapping, Evaluating dan Learning.

Sebagai contoh dalam menjelaskan ruang probabilitas, tentunya mahasiswa masih awam tentang materi yang diajarkan karena memang merupakan hal yang baru. Untuk itu perlu kiranya diberikan suatu sumber analogi baik dengan gambar maupun cerita yang sudah sangat dikenal mahasiswa atau mungkin mahasiswa justru pernah 
mengalami sendiri (access), misalnya seorang mahasiswa diminta untuk melemparkan 2 buah uang Rp. 500,- untuk dicatat hasil pelemparan tersebut (muncul angka atau gambar). Mahasiswa lain diminta menebak hasil lemparan tersebut.. Akhirnya muncul banyak kemungkinan jawaban mahasiswa. Selanjutnya mahasiswa diharapkan mulai dapat menghubungkan/ menganalogikan antara setiap kegiatan yang terjadi dengan permasalahan ruang probabilitas (mapping), misalkan semua hasil tebakan mahasiswa mahasiswa jika dikumpulkan akan menjadi ruang sampel. Untuk selanjutnya kesimpulan yang muncul dari hasil mapping dievaluasi dengan mengambil keistimewaan dari target (evaluating), misalkan untuk dapat menduga kemungkinan terjadinya suatu peristiwa harus selalu memperhatikan tiga serangkai yaitu ruang sampel, kejadian dan probabilitas. Ketiganya secara bersama-sama membentuk ruang probabilitas. Untuk terakhir dari proses bepikir analogi adalah mengambil pengetahuan baru tentang target yang diperoleh, dan menambahkan dalam memori sehingga pengetahuan baru hasil dari berpikir analogi dapat digunakan untuk akses berpikir analogi berikutnya (learning).

\section{Tahap develope}

Tahap develope meliputi tahap validasi perangkat pembelajaran dan revisi perangkat pembelajaran setelah divalidasi.

a. Tahap validasi perangkat pembelajaran

Pada tahap ini perangkat pembelajaran divalidasi oleh dua validator (dosen Program Studi pendidikan Matematika ) yang ditunjuk peneliti. Hasil validasi perangkat pembelajaran adalah sebagai berikut :

- Hasil validasi rencana pembelajaran

1. Hasil validasi rencana pembelajaran (RP) kedua validator memberikan penilaian bahwa RP dapat digunakan dengan revisi. Saran untuk revisi yang dirangkum dari kedua validator sebagai berikut : skenario pembelajaran belum mencerminkan pemb. peta konsep, lembar amatan agar lebih bisa mengakomodir semua aktivitas mahasiswa dalam proses belajar mengajar dan instrument untuk kerja kelompok perlu ditambah, jika perlu setiap kelompok dibuat soal yang bervariasi.

2. Hasil validasi Bahan Ajar Hasil validasi bahan ajar dari kedua validator menyatakan bahwa bahan ajar dapat digunakan dengan sedikit revisi. Revisi yang disarankan dari kedua validator sebagai berikut : perlu diberikan petunjuk umum dalam menggunakan/mempelajari bahan ajar ini, di setiap bab sebaiknya diberikan kompetensi dasar dan perlu ditambah contoh soal maupun soal-soal pengayaan. Terdapat peta konsep pada 
BAB II yang menurut validator terbalik, yaitu konsep variabel random diskrit/kontinu dahulu baru dilanjutkan konsep fungsi distribusi.

\section{b. Tahap perbaikan perangkat pembelajaran}

Pada tahap ini dilakukan perbaikan perangkat pembelajaran baik RPP maupun bahan ajar. Perbaikan perangkat pembelajaran tersebut tentunya dilakukan berdasarkan pada komentar dari validator untuk setiap perangkat pembelajaran.

\section{Tahap desimenete}

Pada tahap ini, perangkat pembelajaran yang sudah diperbaiki diujicobakan pada kelas sesungguhnya yaitu pada mata kuliah Statistika Matematika I di Program Studi Pendidikan Matematika. Kegiatan uji coba juga dimaksudkan sebagai kegiatan eksperimen untuk menunjukkan pengaruh positif pembelajaran peta konsep melalui pendekatan analogi pada mahasiswa.

\section{B. Penerapan Pembelajaran Peta Konsep Melalui Pendekatan Analogi}

\section{Deskripsi Data}

Data penelitian diperoleh dari rata-rata nilai ujian kelompok kompetensi dasar (KKD) dari mata kuliah Statistika Matematika I. Deskripsi data penelitian untuk kelas eksperimen dan kelas kontrol adalah sebagai berikut :

\begin{tabular}{|c|c|c|c|c|c|c|}
\hline \multirow{2}{*}{ Kelompok } & \multicolumn{3}{|c|}{ Ukuran Tendensi Sentral } & \multicolumn{3}{c|}{ Dispersi } \\
\cline { 2 - 7 } & Rerata & Median & Modus & Min & Maks & Variansi \\
\hline Eksperimen & 77,07 & 75 & 75 & 60 & 95 & 92,83 \\
\hline Kontrol & 69,36 & 70 & 72,5 & 50 & 90 & 74,39 \\
\hline
\end{tabular}

\section{Pengujian Hipotesis}

Pengujian hipotesis ini digunakan untuk mengetahui apakah kelompok eksperimen mempunyai prestasi belajar Statistika Matematika I yang lebih baik dibandingkan dengan kelompok kontrol. Untuk keperluan tersebut digunakan uji t dengan terlebih dahulu dilakukan pengujian prasyarat uji yaitu sampel berasal dari populasi yang berdistribuai normal dan masing-masing populasi mempunyai variansi yang sama (homogen). Hasil uji normalitas dengan metode Lilliefors untuk kelompok eksperimen diperoleh nilai statistik uji 0,1199, sedangkan untuk kelompok kontrol nilai statistik uji 0,1322 yang keduanya lebih kecil dari harga kritik 0.1498 , sehingga sampel dari kedua 
kelompok tersebut berasal dari populasi yang berdistribusi normal. Sementara itu hasil uji homogenitas dengan metode Barttlet, diperoleh harga statistik uji $\chi^{2}=0.392$ yang lebih kecil dari harga daerah kritis untuk tingkat signifikan $5 \%$ yaitu 3.841 , sehingga kelompok eksperimen dan kelompok kontrol mempunyai variansi yang sama (homogen). Hasil uji hipotesis, diperoleh harga statistik uji $t_{\text {hitung }}=3.527$ yang lebih besar dari harga kritis untuk tingkat signifikan $5 \%$ yaitu 1.668 , sehingga $\mathrm{H}_{0}$ ditolak. Hal ini berarti bahwa kelompok eksperimen mempunyai prestasi belajar Statistika Matematika I yang lebih baik dibandingkan dengan kelompok kontrol.

Peningkatan prestasi belajar pada mata kuliah Statistika Matematika I tersebut dari hasil pengamatan peneliti lebih cenderung karena pembelajaran peta konsep dapat memberikan pandangan yang lebih mudah bagi mahasiswa dalam memahami konsep secara utuh, serta memberikan gambaran keterkaitan antara konsep yang satu dengan yang lain. Sementara itu dengan pendekatan analogi, mahasiswa dalam mengupas suatu konsep yang abstrak sangat dibantu dengan perumpamaan yang sangat dikenal mahasiswa, misalnya dengan mengkaitkan dengan materi yang sudah dipelajari sebelumnya maupun dengan kehidupan nyata. Selain itu dengan adanya bahan ajar kuliah yang diberikan secara cuma-cuma juga sangat membantu mahasiswa untuk belajar yang lebih tertata dan tentunya dapat meningkatkan semangat belajar mahasiswa.

\section{KESIMPULAN DAN SARAN}

\section{A. Kesimpulan}

Berdasarkan hasil dan pembahasan dengan memperhatikan tujuan penelitian, maka dapat ditarik suatu kesimpulan :

1. Perangkat Pembelajaran yang dikembangakan dalam penelitian ini berupa bahan ajar dan RPP untuk mata kuliah Statistika Matematika I yang mengacu pada pembelajaran peta konsep melalui pendekatan analogi.

2. Terdapat pengaruh positif pembelajaran peta konsep melalui pendekatan analogi pada mata kuliah Statistika Matematika I di Program Studi Pendidikan Matematika Fakultas Keguruan dan IImu Pendidikan Universitas Sebelas Maret Surakarta. Pengaruh positif tersebut ditandai oleh meningkatnya motivasi dan kreatifitas belajar mahasiswa yang diikuti dengan peningkatan prestasi belajar mahasiswa setelah diberi perlakuan dengan pembelajaran peta konsep melalui pendekatan analogi. 


\section{B. Saran}

Berdasarkan hasil penelitian ini, saran yang dapat peneliti sampaikan yaitu:

1. Untuk mengurangi kelemahan mahasiswa dalam memahami konsep yang sering terjadi dalam mata kuliah Statistika Matematika I, maka disarankan pada pengajar mata kuliah tersebut hendaknya menghindari pembelajaran yang cenderung mekanistik yang hanya mengajarkan bagaimana menggunakan cara atau prosedur tetapi lebih menekankan pada pembelajaran yang lebih konseptual dengan banyak menjelaskan konsep dengan perumpamaan yang sudah sangat dikenal mahasiswa.

2. Dengan terdapatnya pengaruh positif penggunaan peta konsep melalui pendekatan analogi, maka pembelajaran ini dapat dijadikan referensi menarik bagi para pengajar, khususnya dalam upaya mengatasi kelemahan mahasiswa dalam memahami konsep yang sering terjadi dalam mata kuliah Statistika Matematika I.

\section{DAFTAR PUSTAKA}

Glynn, S. M. (1996). "Teaching with analogies: Building on the science textbook". The Reading Teacher. 49(6)

Kolodner, J. L. (1997). "Educational implications of analogy: A view from case-based reasoning". American Psychologist. 52

Martin, M.A. (2003). "It's Like ... You Know : The Use of Analogies and Heuristics in Teaching Introductory Statistical Methods" Journal of Statistics Education. 11 (2).

Moh. Amien. (1984). Pemetaan Konsep Suatu Teknik untuk Meningkatkan Hasil Belajar yang Bermakna. Yogyakarta: FMIPA-IKIP

Neter,J.W. , Waserman and M.H. Kutner (1990). Applied Linear Statistical Models. 3rd ed. Ricard D. Irwin inc, Homewood, Illinois.

Novak, J. D \& Grown D. B. (1984). Learning How to Learn. Cambride: University Press.

Sowey, E. R. (1995). "Teaching Statistics: Making it Memorable." Journal of Statistics Education. Vol 3.

Ratna Wilis Dahar (1989). Teori Belajar. Erlangga, Jakarta. 